\title{
Analysis of Stunting Based on Cultural Approach to Ogan Komering Ilir Community South Sumatra Province
}

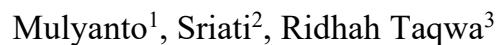 \\ \{marius_mulyanto@yahoo.co.id ${ }^{1}$ \} \\ Universitas Sriwijaya, Indonesia ${ }^{1,2,3}$
}

\begin{abstract}
Based on the stunting condition in Indonesia, the government intervened the stunting in 100 priority regencies/cities based on the criteria for the number and prevalence of stunting toddlers. Ogan Komering Ilir (OKI) Regency is one of the intervention targets in South Sumatra Province. The stunting rate of OKI according to Riskesdas reached $40.5 \%$ or almost half of toddlers in OKI experienced stunting. There have been many types of research conducted to find its causes that tend to use statistical analysis and focus on medical analysis. Therefore, the problem of stunting is interesting to study using a cultural approach in public life. The purpose of this research is to analyse the cognitive map of the community that forms the basis of cultural knowledge in relation to public health behaviour, as a cause of stunting. This research uses a qualitative approach with a constructivist research paradigm and ethno science strategy. The results show that stunting toddlers are mostly in residential areas near rivers, specifically the Komering River and the Lempuing River. The stunting toddler family is a local resident, originating from the Kayuagung Tribe. They're still live simple lives and make living as farmers as well as river fishermen. Rivers become the orientation of their daily lives and it tends to be in subsistence conditions. Stunting is caused by the parenting cultural patterns that cannot be separated from the orientation system of cultural values as a lifestyle.
\end{abstract}

Keywords: Stunting, Cultural Approach, Community, South Sumatra, Indonesia

\section{Introduction}

The term stunting varies, but basically, stunting is a short toddler with low weight and chronic malnutrition, a dwarf and others. According to UNICEF, stunting is defined as the percentage of children aged 0 to 59 months, with height below minus (moderate and severe stunting) and minus three (chronic stunting) measured by the WHO's child growth standards. Stunting is a condition of failure to achieve physical development measured by height according to age. Stunting limits according to $\mathrm{WHO}$ are height by age based on Z-scores equal to or less than -2SD below the standard average (WHO, 2013). The definition is almost the same from that from the Ministry of Health as children under five with z-scores of less than 2SD/standard deviation (stunted) and less than - 3SD (severely stunted) [1].

Chronic nutrition problems due to malnutrition in a long time are generally caused by food intake that does not match nutritional needs. Stunting starts from the womb and is only seen when a child is two years old.

In addition to stunted growth, stunting is also associated with suboptimal brain development, which causes poor mental, learning abilities and school performance. Stunting 
and other conditions related to malnutrition are also considered as a risk factor for diabetes, hypertension, obesity, and death due to infection.

In Indonesia, around 37\% (nearly 9 million) of children under five are stunted and throughout the world, Indonesia is the fifth country with the highest prevalence of stunting [2]. Toddler/children under two/three who experience stunting will have a level of intelligence that is not optimal, making them more vulnerable to disease and in the future, they can be at risk in decreasing levels of productivity. In the end, stunting can hinder economic growth, increase poverty and widen income inequality.

The stunting development process is slow, cumulative and there may be inadequate parenting culture patterns. Growth failure may have occurred in someone's past. Symptoms of stunting in Kompas.com (2017) are: (1) children are shorter than others of their age; (2) their body proportions tend to be normal but they look younger/smaller for their age; (3) they have low weight for their age; and (4) their bone growth is delayed [3].

The cause of stunting develops in the long run due to a combination of some or all of the following factors: (1) chronic malnutrition for a long time, (2) intrauterine growth retardation, (3) inadequate protein in the proportion of total calorie intake, (4) hormonal changes triggered by stress, and (5) often suffering from infection early in a child's life [1].

International experience and evidence show that stunting can hamper economic growth, reduce labor market productivity, resulting in the loss of $11 \%$ of Gross Domestic Products (GDP), and reduce the income of adult workers by up to $20 \%$. In addition, stunting can also contribute to widening the gap, thereby reducing $10 \%$ of total lifetime income and causing inter-generational poverty [1].

Based on the stunting condition in Indonesia, the government intervened the stunting in 100 priority regencies/cities based on the criteria for the number and prevalence of stunting toddlers. The government at the national level has issued various policies and regulations which are expected to contribute to reducing stunting prevalence.

Out of 100 priority districts/cities, Ogan Komering Ilir (OKI) Regency is one of the intervention targets in South Sumatra Province. One of the regions in Indonesia with the highest stunting rate is OKI Regency. The stunting rate of OKI according to Riskesdas reached $40.5 \%$ or almost half of toddlers in OKI experienced stunting. In fact, this number is above the national stunting rate of $37 \%$. Even though based on the data in 2017, there had been a decrease, it is still above the prevalence. According to the Indonesian Ministry of Health (2013), if the stunting prevalence rate is above the cut of $(>20 \%)$ that has been universally agreed upon, it is still a public health problem.

There have been many researchers conducted with a focus on stunting, such as the research by Ni'mah and Nadhiroh [4], and the research conducted by Aridiyah, et al. [5]. In those researches, they use statistical analysis and research variables that focus more on medical analysis.

Therefore, the problem of stunting is interesting to research with a focus on the stunting analysis using a cultural approach in community life. This research analyzes whether the values, norms and customs and behaviors of the community as a guide to the cultural value system are factors that influence and cause stunting. The purpose of this research is to analyze the cognitive map of the community that forms the basis of cultural knowledge in relation to public health behavior, as a cause of stunting. 


\section{Research Method}

This research uses a qualitative approach with the ethno science research strategy. An ethno science research strategy is a cultural approach [6]. The ethno science strategy emphasizes more on efforts to uncover the cultural patterns used by the community to classify the environment or social situation encountered. This research explores the principles used by community members or positive maps that form the basis of cultural value orientation systems in their lives.

Unit conceptualization was found by analyzing the positive processes and structures of the people under the research. The researcher performed interpretation and analysis of the meaning of ways of thinking, ways of acting and lifestyle of the people with the stunting phenomenon.

\section{Result and Discussion}

\subsection{Location and Identity of Stunting Family}

The stunting target areas in OKI in 2019 are 5 (five) districts expanded to 10 districts in 2020. This research was conducted in Tanjung Lubuk, Padamaran, Lempuing Jaya and Sirah Pulau Padang Districts.

Based on data from each health center, the stunting area is spread over several villages. In Tanjung Lubuk Health Center, there are 2 toddlers in Sukarame Village. In Pedamaran Health Center, stunting is spread in Suka Damai Village of 4 toddlers, in Pedamaran Village 1 of 4 toddlers and in Cinta Damai Village of 6 toddlers. In Rantau Durian Health Center in Lempuing Jaya District, there are 10 toddlers in Tanjung Sari Village. In Sirah Pulau Padang Health Center, there are 22 toddlers in Ulak Jermun Village, 15 toddlers in Penyandingan Village, 15 toddlers in Bungin Tinggi Village, and 19 toddlers in Berkat Village.

Most families with stunting children reside by the river, namely Lempuing and Komering Rivers. The stunting children tend to be the residents and claim to be from Kayuagung Tribe. Kayuagung tribe calls itself Morge Siwe which is a merger of two puyang or descendants from Puyang Abung Bunga Mayang from Lampung Residency and Puyang Komering Batak.

At first, the two puyangs were located differently, but the villages built were on the banks of Lempuing and Komering Rivers and the tributaries of the two rivers. In its development, the Puyang Abung indigenous community is centered in Perigi Village and the Puyang Komering Batak indigenous community in Kayuagung Village. During the Sultanate of Darusalam Palembang, the two puyangs were put together as "Morge Siwe" (nine clans). These nine clans are the expansion of some villages, namely Kayuagung, Perigi, Kotanegara, Kedaton, Sukadana, Paku, Mangunjaya, Sidakersa, and Jua-Jua. These villages are now the village area in Kayuagung District.

The livelihood of the Kayuagung Tribe at that time was trading with river transportation modes, such as in Komering River, Lempuing River, Mesuji River, and Ogan River. Since a long time ago, they have sold food, household appliances made from pottery and other household materials. The natural conditions are dominated by forests and swamp forests, swamps, especially swamps that are used for rice farming and fisheries, and several large rivers such as Komering River, Lempuing River, Ogan River, and their tributaries. 
The Kayuagung tribe as a cultural system has a unique diversity of customs, such as language, art and marriage ceremonies and the people who still uphold customary rules. Custom is a system of values, culture, and outlook on life and ideology. Among the various kinds of Kayuagung's customs that are currently used and upheld by the community is the birth of a baby, marriage, and death which is regulated and guided by local cultural customs.

The strong Kayuagung's customs in its people's lives make the cultural identity obeyed and respected. One custom that is a strong identity is the custom of marriage. In this customary process, the bride carries a lot of luggage (Oban in local term) in the form of household appliances, such as beds, guest chairs, wardrobes, and ornamental cupboards, cooking and eating utensils. This bride's luggage shows the identity and dignity of women who do not want to get married using the appliances, not of her own.

Based on the analysis, this customary behavior is the cause of toddlers experiencing stunting. Women's dignity is a cultural value system so that parenting in the family culturally is orientated to materials. Village midwives and health centers are lacking awareness of pregnancy checks. Likewise, in the birth process, although there are midwives as the medical staffs in the village, people still rely on traditional birth attendants (dukun beranak) to help them. Traditional birth attendants assume that the first breast milk should not be given to the baby children as it is stale. The first breast milk is medically the breast milk that gives the child immunity from disease.

Limited knowledge of both formal education and the tradition of the material cultural value system are the cause of stunting toddlers. The families are orientated to "luxurious" lives by having jewelry rather than taking care of and nurturing their children.

\subsection{Parenting Culture}

In every society, family is a social institution that is very important for social life. People spend most of their time in the family compared to at work. A family is a place where children are conditioned and prepared for their roles later in the adult or social world in their lives. Through learning the role in the family, the preservation of various institutions and cultural values in the community occurs. It is like the family is a bridge that connects individuals who develop with a social life for their roles when they are adults. Individuals, who are born in families and develop, experience the learning process that will adopt the values that are generally applicable in their communities and are expected to play the role they do in the social world.

The families prepare themselves to give a certain orientation to the life journey of a growing child. Therefore, each family has its own characteristics as a result of its development process, so it becomes certain characteristics or norms in the family system in different societies. The influence of early behavior on a child from the family and the next stage are various influences from other social environments, which can also imprint on the child's individual development.

Cultural patterns of the family care for the Kayuagung Tribe have customs and norms that have a cultural orientation that tends to prioritize material needs rather than meeting the needs of the interests of growth and development of children. This tendency occurs in families of the Kayuagung Tribe who reside in the research site. This happens because their lives are grouped into communities that come from the same area. Their daily lives are not different from others, but they have different parenting. Since the pregnancy, mothers rarely do checkups to medical personnel, both village midwives and health centers, for various reasons, such as they have no time, the health center is far away from home, and their husbands do not want to take them. 
At the time of delivery, some use medical personnel, but some others still rely on traditional birth attendants, also for various reasons. They are considered to have more experience in helping births than village midwives who are mostly young.

They tend to apply the culture pattern of breastfeeding to their babies. However, before the feeding time, the babies have been given additional food or milk that is not for them. The pattern of spoon-feeding in children is also unscheduled, so whenever their children want to eat, they are given food. However, if they do not want to eat, their mothers just let it happen, so they have irregular food patterns. If the children do not want to eat, their mothers tend to give the food that they want. In general, the research found that when children can eat, mothers will give various kinds of instant foods sold in stalls. In fact, these kinds of foods are not for children yet. They have no nutrition and contain food preservatives. There is a tendency for mothers to feed their children only with the types of foods and drinks that they love, such as snacks with MSG, sweetened condensed milk, sausages, and instant noodles that are not allowed to be consumed by toddlers. The impact of this food consumption is that children who often experience diarrhea, are easy to get sick and have low mindset.

This is done by the mother because it is considered that the child would want to eat and is not troublesome. Even though the mother's role is only taking care of the household, they do not feed their toddlers according to age development. They prefer a chat with their neighbors. Some even use drugs as their lifestyle. This fact shows the orientation of the present value system even though their living conditions are subsistent.

According to UNICEF [7], there are two main factors causing stunting, namely food intake and infectious diseases. World Bank [6], added the factor of birth weight status. The results of this research indicate that birth weight tends to be normal. It is precisely the factor of the parenting cultural value orientation system that contributes to stunting.

It seems that there is a correlation between mindset and consistency of thought which is limited to their community, so knowledge and experience become the value orientation systems in their cognitive maps. Social transmission from outside the community is considered to change the structure of the value system. Therefore, to maintain the value orientation system, pregnant women do not want to follow the advice of village midwives or health cadres to always weigh and check the health of their toddlers in the Integrated Services Post or Village Health Post.

It is implied that for children to grow and develop normally, comprehensive family education is needed, especially for local families, to expose the cultural value orientation system which is the cause of stunting. Stunting children will be a big burden for the continued growth and development of the children, families, and society, especially the country.

\section{Conclusion}

The development of stunting requires a process, runs slowly, and is interrelated, so it should be prevented since the child is in the womb and during the first 24 months of life. Based on these research data, there is a tendency when children are born under normal conditions, there are one or two children born with low birth weight. However, pregnant women still need to know and maintain the development of pregnancy and conduct medical check-ups.

At the beginning of life, we should focus on the importance of knowledge of first breastfeeding, exclusive breast milk, supplementary feeding when children are older than 6 
months, and food intake needed by both the child and mother for the normal child's development which continues to adulthood. So far, stunting has only been analyzed medically. There has not been much analysis of stunting from cultural value factors. As every community has a different cultural value orientation system that becomes a guide in their lives, values and norms in the cultural value orientation system in each community need to be further examined.

\section{References}

[1] Tim Nasional Percepatan Penanggulangan Kemiskinan, 100 Kabupaten/Kota Prioritas Untuk Intervensi Anak Kerdil (Stunting). Jakarta, 2017.

[2] Kementrian Kesehatan Republik Indonesia, Laporan Hasil Riset Kesehatan Dasar (Riskesdas) Tahun 2013. Jakarta, 2013.

[3] "Mengenal 'Stunting' dan Efeknya pada Pertumbuhan Anak"," Kompas, 2017. .

[4] K. Ni'mah and S. R. Nadhiroh, "Faktor yang berhubungan dengan kejadian stunting pada balita," Media Gizi Indones., vol. 10, no. 1, pp. 13-19, 2016.

[5] F. O. Aridiyah, N. Rohmawati, and M. Ririanty, "Faktor-faktor yang Mempengaruhi Kejadian Stunting pada Anak Balita di Wilayah Pedesaan dan Perkotaan (The Factors Affecting Stunting on Toddlers in Rural and Urban Areas)," Pustaka Kesehat., vol. 3, no. 1, pp. 163-170, 2015.

[6] "The World Bank," 2007.

[7] "Unicef," 1998. 